\title{
MULTIPLE MEDIATIONS: Feminist Scholarship in the Age of Multinational Reception
}

\author{
Lata Mani
}

\begin{abstract}
' "unusual knowing", a cognitive practice, a form of consciousness that is not primordial, universal, or coextensive with human thought. [. . .] but historically determined and yet subjectively and politically assumed' (de Lauretis, March 1990).
\end{abstract}

On the acupuncturist's table, Berkeley, California, July 1988.

I am lying in wait for the complex verbal negotiation that attends each visit to my acupuncturist. I want a diagnosis - a definable illness, a definite cure. He is disdainful of this desire for clarity and resolution and insists on treating my body as a zone in which energies rise and fall, sometimes rebelliously, at other times gracefully and once even, as he put it, 'stroppily'. As I ponder the frustrating untranslatability of his idiom, he asks the dreaded question: 'Well, what is your Ph.D. thesis about?'

I stare at the infra-red lamp and wonder which version to present. The various responses I have elicited over the years race through my mind like a film running at high speed. My usual strategy is to assess the cultural politics of those addressing me (such as I can discern them), the tenor of the question (is this a serious inquiry or merely a polite one?) and my frame of mind at the time (do I want to educate, be patronized or try to avoid both by being vague, but thereby risking the impression that I know not what I am doing?). I did not, however, have time for such musings. I was trapped under the beady eye of my white American doctor of needles who, having taken my pulse, was awaiting a reply. So I blurted out what I consider my minimalist 'no-nonsense' description: 'I am working on the debate between colonial officials, missionaries and the indigenous male élite on sati (widow burning) in colonial India.'

I felt weak, as though it had been a confession extorted from me after intense cross-examination. I sighed inwardly. Meanwhile, my declaration had provoked what turned out to be a half-hour lecture on the 
dilemmas of cross-cultural understanding. He said that such practices would always be difficult for Westerners to comprehend, hastily adding that it was important none the less not to impose alien values and that sati probably had a particular significance within Indian culture which it would be enlightening to know. At this point he turned away from my foot, into which he had just finished inserting needles, and asked, 'So how do you understand widow burning?'

I felt myself stiffen. He had thrown me a challenge that would require a command performance in colonial and post-colonial history and discourse, one that I did not feel equal to at the time. So I said evasively, 'It's a long story and I'm trying to sort it out.'

'Good', said the genial man in the white coat tapping my arm. Not waiting for a response, he continued. 'Of course, you are Westernized and your ideas have probably changed from living here. I wonder what women in India feel about it?'So saying, he left the room.

I was furious. I had not interrupted his liberal, relativist, patronizing discourse, and was as a result caught in its pincer movement: an apparent but ultimately repressive tolerance, a desire for 'true' knowledge, and a demand for authenticity that was impossible for me to meet, given that any agreement between us, however fragile and superficial, would immediately make me 'Westernized': not like 'them'but like 'him'. I wished for the millionth time that I had been working on a less contentious topic, one that, unlike sati, had not served as metonym for Indian society itself . . or had had the panache to wag my finger like him and say, 'Read my book and you'll find out'.

\section{The emergence of a politics of location}

This paper explores questions of positionality and location and their relation to the production of knowledge as well as its reception. These issues have animated feminism from its inception. Here they are approached through a set of interconnected reflections, on the processes that shaped my study of debates on sati under British colonialism, and on the different ways in which this analysis has been received in Britain and in India. Such alternative readings thematize the politics of intellectual work in neo/post-colonial contexts, and the difficulties of achieving an international feminism sensitive to the complex and diverse articulations of the local and the global.

Contemporary theory in feminism and in the humanities has brought a critical self-consciousness to bear both on the place and mode of enunciation (who speaks and how) and that of its reception (how it is interpreted and why). As claims to universality and objectivity have been shown to be the alibis of a largely masculinist, heterosexist and white Western subject, both readers and writers have had to confront their particularity and history. Gender, race, class, sexuality and historical experience specify hitherto unmarked bodies, deeply compromising the fictions of unified subjects and disinterested knowledges. 
Such developments, or should I say acknowledgements, require attentiveness to the theoretical and political impulses that shape our projects, and an openness to the inevitable fact that different agendas may govern their reception. Needless to say, there have always been multiple investments and diverse audiences. Our accounting of these phenomena today simply attests to the successful struggles for discursive spaces of those overlapping and hitherto marginalized groups, women, Third World people, gays and lesbians. Institutional concessions to the heterogeneity of the social landscape has prompted the emergence of new fields of study within US universities, for instance ethnic studies and women's studies. It has also given new momentum to interdisciplinary work. The current mobilization of talents and energies around culture studies is a case in point. ${ }^{1}$

The revolt of the particular against that masquerading as the general, of what Donna Haraway has called 'situated' as against 'disembodied knowledges', (Haraway, 1988) has brought to the fore theoretical and political questions regarding positionality and identity. This issue has probably been most fully developed within feminism, in part in debates about the relationship between experience and knowledge. One locus of such discussion in the Euro-American context has been the related struggles over racism and white centredness of dominant feminism (Moraga and Anzaldua, 1981; hooks, 1981, Amos et al., 1984; Bhavnani and Coulson, 1986, among others) and its replication of elements of colonial discourse (Spivak, 1981; Mohanty, 1984; Minh-ha 1986/7; Lazreg, 1988). Feminists have called for a revised politics of location - 'revised' because, unlike its initial articulation, the relation between experience and knowledge is now seen to be one not of correspondence, but fraught with history, contingency and struggle (In addition to the authors already cited, see Bulkin et al., 1984; Segrest, 1985; Rich, 1986; de Lauretis, 1986; Kaplan, 1987). ${ }^{2}$ These terms powerfully suggest some of the problems of positionality as they confront me: a post-colonial Third World feminist working on India in the United States.

Chandra Talpade Mohanty argues that developing a politics of location requires exploration of 'the historical, geographic, cultural, psychic and imaginative boundaries which provide the ground for political definition and self-definition' (Mohanty, 1987: 31). Location, in her terms, is not a fixed point but a 'temporality of struggle', (p. 40) characterized by multiple locations and nonsynchronous processes of movement 'between cultures, languages, and complex configurations of meaning and power.' (p. 42) These processes, in Mohanty's view, enable 'a paradoxical continuity of self, mapping and ... political location ... $[\mathrm{M}] \mathrm{y}$ location forces and enables specific modes of reading and knowing the dominant. The struggles I choose to engage in are then the intensification of these modes of knowing.' (p. 42).This definition of the space of politics very nicely illuminates the dynamics of how my conception of a project on the debate on sati in colonial India bears the traces of movement between cultures and configurations of meaning, multiple locations and specific modes of knowing. 
My research examines colonial official, missionary and indigenous élite discourses on sati in Britain and India in the late eighteenth- and early-nineteenth centuries. I investigate the conditions of production and the burden of each of these discourses, the intersections, differences and tensions between them, and the competing and overlapping ways in which they were deployed. Among other things, I argue that a specifically colonial discourse on India framed the debate on sati, producing troubling consequences for how 'the woman's question' in India was to be posed thereafter, whether by Indian nationalists, or Western feminists (Mani, 1989).

One of the things that has prompted and sustained my energy through hours of plodding through archival documents and reels of dizzying microfilm has been a conviction of the importance of the contemporary ideological and political legacy of such debates about women and culture. I have always been aware that this legacy has had a differential trajectory in India and in, for example, the US or Britain: that the relation of this earlier discourse to contemporary knowledges, popular and specialist, about India in the West, was different from its relation to the contemporary self-knowledge of Indians. It is the contours of this difference that this paper will now explore.

The following section reflects on the experience of presenting my work (Mani, 1987) to groups in the US, Britain and India and discovering that the audiences in these places seized on entirely different aspects of my work as politically significant. These responses in turn have caused me to reflect on how moving between different 'configurations of meaning and power' can prompt different 'modes of knowing'. The experience has also required me squarely to confront a problem not adequately theorized in discussions of positionality or of the function of theory and criticism: the politics of simultaneously negotiating not multiple but discrepant audiences, different 'temporalities of struggle'. ${ }^{3}$

\section{Back to the future: the after-lives of colonial discourses}

'Colonial' or Eurocentric discourses on India, and on the Third World more generally, have an abiding presence in the USA and Britain, the two Western countries with which I am most familiar. Television documentaries, scholarly writing and popular wisdom circulate such notions as the centrality of religion - whether framed as the essential 'spirituality' of the East or as the dominance of caste (Inden, 1986; Appadurai, 1988) - the antiquity of Indian 'culture', and the victimization of women. These ideas 'hail' those of us living here with a systematicity that, over time, makes them truly oppressive. As a Marxist-feminist who had come to feminism in India, I initially responded to the predominance of culturalist understandings of Indian society with surprise and bemusement at the ignorance they betrayed. I 
assumed that such ignorance must also account for my having so often to explain the supposed anomaly of being an Indian feminist.

The repetition of such incidents as my encounter with the acupuncturist, the dynamics of which I would barely have been able to fathom when I first arrived in the US, compelled me to think seriously about the prehistory of such knowledges about India and Indian women. I brought this new sensibility to bear on reading the debate on sati. It has been, I believe, by and large productive. For although I have read many of the same documents as other historians, Indian and nonIndian, an alertness to how British colonialism may have shaped knowledge about colonized society has turned up unexpected disjunctures, contests and determinations, for instance, over what constitutes 'tradition'. Given a context in which elements of this nineteenth-century discourse continue to circulate, on occasion virtually unreconstructed, in the service of British racism and US cultural imperialism, I consider excavation of the colonial prehistory of such ideas to be a political gesture.

By and large, most discussions that followed presentations of my work in the US or Britain tended to focus on the contemporary replications, resonances or rearticulations of what I had sketched. In Britain, for instance, we explored how the British state manipulates women's 'oppression' in Indian and Pakistani 'culture' to legitimate virginity tests, immigration controls and policing of Asian marriages and family life. This 'civilizing' racist British state has placed black feminists in Britain in a position analogous to that of nineteenthcentury Indian male social reformers, who defended 'culture' and 'women' in a similarly overdetermined context (Parmar, 1982; Amos et al., 1984; Grewal et al., 1988). The significant difference between then and now is that black feminists (unlike many male nationalists) have insisted on keeping women at the centre of the struggle, refusing to let themselves become mere pawns in a contest between the state and community. They have charted a complex strategy. On the one hand, they have challenged the self-serving appropriation of 'women's issues' by a racist British state. Simultaneously, they have resisted both the 'protection' of men in the black community when it has come with a defence of practices oppressive to women, and white feminist attempts to rescue them from patriarchy. In short, black feminists in Britain have refused 'salvation', whether by the state in the name of civilized modernity, by black men on behalf of tradition and community integrity, or by white feminists in the interest of ethnocentric versions of women's liberation. In this context, discussions after my presentations explored, among other things, questions of rhetoric and strategy: how to argue for women's rights in ways that were not complicit in any way with patriarchal, racist or ethnocentric formulations of the issues. Thus, given that the British state draws on key elements of nineteenthcentury discourses on India to further its own current projects, my delineation of the colonial dimension of these discourses was seen to have an explicitly political character. 
In India, however, this dimension of my project was interpreted quite differently, primarily as an academic and historical argument. To some extent this is not surprising. Notions of 'timeless textual traditions' or the essential spirituality of Indian society have a different afterlife in the Indian public domain. Quite simply, they are not, as in Britain, critical to the elaboration of hegemony. Certainly, development policies explicitly embrace the logic of modernity, brahmanical texts have come to represent quintessential Hinduism, and the colonial legacy of making religious scriptures the basis of civil law has enormously complicated feminist projects of legal reform. However, notions like 'timeless traditions' function most often to inspire literature from the Indian Tourist Development Corporation or to feed the fantasy life of petit-bourgeois middle- and high-caste Indians regarding the glory of ancient India (read, 'of their own lineage'). Except in the case of Government of India documentaries on tribal peoples, or sometimes in relation to remote rural areas, there does not exist a serious convention of representing Indian citizens as lacking agency, inhabiting a timeless zone, and immobilized by 'tradition'. Indeed, this kind of analysis would be difficult to sustain, given that the authority of the Indian state has been continually challenged since independence, and is bolstered today not by a democratic consensus but through a brutal and increasingly unashamed use of violence.

The Indian context thus presents a sharp contrast to the West; naming something 'colonial' in India has, accordingly, a different import. It becomes a question of periodization, rather than a crucial move in developing an oppositional, anti-imperialist critical practice. Such a reading is further comprehensible because, in a palpable, existential sense, when one is in India, colonialism does indeed seem like a thing long past. Despite India's economically dependent status in the world economy and its wilful exploitation by multinationals and agencies like the World Bank, 'the West' as ideological and political presence articulates with such a density of indigenous institutions, discourses, histories and practices that its identity as 'Western' is refracted and not always salient. This is not to say that Indians are naive about the impact of the West. (There was, for example, little confusion about the ultimate culpability of the US-based corporation Union Carbide, in the Bhopal industrial disaster.) What I am suggesting is that, unlike, for example, many nations in the Caribbean or in Central America, in India it is not the boot of imperialism that is felt as an identifiable weight upon one's neck. The pressure one feels compelled to resist is rather that of the nation state, dominant social and political institutions, and religious 'fundamentalisms' of various kinds. No doubt, the activities of the nation state are themselves related in complex ways to regional and global geopolitical trends, but it is the local face of this international phenomenon against which one is moved to struggle.

It comes as no surprise, then, that in India, the 'political' dimension of my work is seen to be expressed primarily in my engagement with 
nationalism, the limited parameters within which nationalists posed the question of women's status, the marginality of women to nineteenthcentury discussions supposedly about them, and the legacy of colonialism in contemporary discussion of women's issues. This last point was made in my presentation in relation to the recent controversy over reform of Islamic law provoked by the 'Shahbano case'. The case was one in which the Supreme Court had upheld the application of a Muslim woman, Shahbano, for lifelong maintenance from her ex-husband. The Supreme Court's verdict became a rallying point for many Muslims who felt that the court had (contrary to its claims) violated Islamic law and thus undermined the only legal protection Indian Muslims enjoyed as a religious minority (Punwani, 1985; Kishwar, 1986; Engineer, 1987; Pathak and Sunder Rajan, 1989). In analyzing the case, it was possible to point out how, in this as in many instances in the nineteenth century, contests over women's rights were being debated as contests over scriptural interpretation, and as struggles over a community's autonomy and right to self-determination. While these terms do not exhaust the arguments made in relation to the case, they point to significant parallels between nineteenth- and twentieth-century debates on women. (Mani, 1987: 153-6). My interest in such continuities was in the ways in which they constrained the form and content of contemporary discussions. I did not assume that the persistence of certain discursive elements implied unchanged significance, meanings or effects; ideas are potentially available for different kinds of appropriation by different social forces. Suffice it to say that the case, more than any theoretical argument about 'colonial discourse', served to convey some of the political impulses of my project. Even here, however, the 'colonial' dimension was of academic interest. The burden of the discussion, not inappropriately, fell to the practical problems of building coalitions between Hindu and Muslim women in the wake of the divisiveness produced by the Shahbano case and the growth of communalism in Indian politics.

\section{Situating our interventions}

These differing receptions of my work in Britain and India raise questions regarding the relationship between 'experience' and 'theory', one's geographical location and the formulation of one's projects. It seems to me that travelling to the US and living under its regimes of truth regarding India and the Third World more generally have intensified for me certain 'modes of knowing'. The disjunctions between how I saw myself and the kinds of knowledge about me that I kept bumping into in the West, opened up new questions for social and political inquiry.

Reading Edward Said's Orientalism in this context was enormously productive and energizing (Said, 1979). It contextualized the phenomena, discourses and attitudes I was encountering and helped me in 
the task of situating personal experiences within a historical problematic. It quickened my impulse to take more seriously than I had previously been inclined to, colonial official and missionary discourses on India. My interest in these was not merely that of a historian of ideas, but of someone curious about the history of the present. I can only wonder at how my project might have been fashioned in the absence of this experience of travel to a different economy of power and knowledge. In this regard, I find it significant that an Indian friend of mine once remarked that the full force of Said's argument in Orientalism had come home to her only after spending time in Europe. Prior to this she had believed, and this is a fairly common perception in India, that Said was perhaps overstating his case, stretching a point. ${ }^{4}$

It seems to me that the politics and epistemology of differing readings such as these dramatizes the dilemma of post-colonial intellectuals working on the Third World in the West. One diagnosis of this situation accuses such intellectuals of inauthenticity or ideological contamination by the West. This charge may be levelled by First World intellectuals demanding a spurious authenticity of their Third World colleagues. It often works to challenge the latter groups' credibility, by implying that their politics are exceptional and ungeneralizable. This analysis may, however, also be shared by Third World intellectuals working in the Third World. The criticism in this instance may be rooted in the assumption, not always unwarranted, that intellectuals abroad are, so to speak, 'selling out'. It is, however, ultimately simplistic because it overgeneralizes, and one does not, of course, have to leave home to sell out. Alternatively, assertions about ideological contamination are often shorthand allusions to genuine issues, such as asymmetries in the material conditions of scholarship in metropolitan and Third World contexts. Such problems are, however, not clarified by a moralistic formulation of the issue in terms of purity or pollution.

In the face of this discourse of authenticity, some Third World intellectuals working in the First World have reterritorialized themselves as hybrid. This strategy is compelling when such a demonstration of hybridity becomes, as in Gloria Anzaldua's Borderlands (1987) an enabling moment for the possibility of a collective politics attentive to difference and contradiction. When, however, the elaboration of hybridity becomes an end in itself, serving only to undo binary oppositions, it runs the risk of dodging entirely the question of location. To this one must say, 'necessary but insufficient'.

Finally, for those intellectuals from the geographical Third World who have an elsewhere to return to, there is the possibility of adopting a tactic which would separate projects into what is deemed appropriate or inappropriate to do 'while one is in the West'. Here again we have a prescription which may make sense in specific instances, for political and practical reasons. On the other hand this strategy also has the potential for side-stepping the issue. It implicitly conceives of the West and non-West as autonomous spaces and thereby evades the thorny issue of their intersections and mutual implications (Mohanty, 1989). 
How, then, would I proceed to delineate, in my own case, the potential and limits of my location, working on the Third World in the belly of the First? For one thing, it seems to me that the mode of knowing enabled by the experience of existing between discursive systems makes it difficult for me to isolate colonialism as a distinct historical period with little claim on the present. Consequently, I have tried to train myself to look for discontinuities in apparently smooth surfaces, and continuities across the dominant and oppositional. Secondly, the deadening essentialism of much historical and contemporary Western representation of the Third World has confirmed for me, albeit in a different way, a lesson learnt earlier from Marxism: an abiding suspicion of primarily cultural explanations of social phenomena. At the same time, perhaps not paradoxically, experiences of such a persistent privileging of 'culture' have in turn compelled me to take very seriously the domain designated by it. What counts as 'culture'? How is it conceived and represented? With what consequences? In short, I have been persuaded of the need to open to critical reflection the vexed and complex issue of the relationship between colonialism and questions of culture.

This is a problem that is, to my mind, yet to be adequately thematized in the literature on colonialism in India. Historiography on nineteenth-century India, for instance, has produced sophisticated analysis of the impact of colonialism on India's economy and politics, but has paid comparatively little attention to its impact on culture or on conceptions of it. Perhaps the ways in which I may be tempted to frame the problem will be marked by the fact that it became an issue for me as a result of my experience of Britain and the US. It may be that I accent the colonial rather more heavily than my imagined counterpart, the feminist writing in India. But as I reflect on what moves me, I also need to be aware that I now inescapably participate in multiple conversations, not all of which overlap. As for the gains of being situated in the interstices, only time will tell. In the meantime, it seems to me that my attempt to specify location might also be fruitfully undertaken in dialogue with feminists in India. After all, the dangers of reading the local as global are potentially present both in India and in the West: in the former through minimizing colonialism, in the latter through aggrandizing it.

\section{Priorities redetermined: the aftermath of Roop Kanwar's burning}

The difficulties of straddling different temporalities of struggle cannot, however, always be resolved through listening for and talking about our specificities. There are political moments which pose limits to the possibility of conceiving of international feminist exchanges (whether between First and Third World women in the West or between Third 
World women cross-nationally) as negotiated dialogues which, while they may alternately diverge and intersect, are ultimately benign and noncontradictory.

On 22 September 1987, Roop Kanwar died on the funeral pyre of her husband in Deorala, Rajasthan. The incident has sparked off a nationwide controversy on sati in India, unearthed the information that there have been at least thirty-eight widow immolations in Rajasthan since independence, and dragged out of the closet vociferous supporters of the practice. In this recent case, the government of India vacillated in taking action against family members found to have coerced Roop. State officials were present along with an estimated 300,000 others at an event 'honouring' the episode thirteen days after the burning, and when the state finally banned glorification of sati, the response was too little, too late.

Meanwhile, a massive debate on sati had been set in motion, with opponents and defenders staking out their claims in terms that were in many ways remarkably reminiscent of the nineteenth-century controversy which is the subject of my own research. As in the colonial period, issues of scriptural interpretation, the so-called 'traditional' nature of sati, its barbarity, the role of the state, women's social conditioning and the question of the widow's consent, all emerged as key items in the debate.

Four positions were discernible in the discussions that followed upon Roop Kanwar's death. Each of these is more elaborate than my characterization of it suggests, but my purpose here is merely to sketch in broad strokes the discursive space that was constituted, referring readers to others who have analyzed them more thoroughly (Patel and Kumar, 1988; Sangari, 1988, among others). There was firstly, a 'liberal' position, critical of sati as 'traditional,' 'religious' and barbaric and arguing that the incident represented the failure of the project of modernization. Secondly, and opposed to this, was the conservative, pro-sati lobby. This valorized sati's 'traditional' and 'religious' status and argued that the rationality of the practice was necessarily inaccessible to westernized, urban Indians.

Ostensibly critical of both these positions, although reserving the burden of its critique for the former and ultimately aligning itself with the latter, was a third stance (Nandy, 1987, 1988a, 1988b). Ashis Nandy, a trenchant critic of the philosophies of modernization and development, castigated liberal condemnation of sati as the response of a rootless, decultured urban bourgeoisie, unable, if not unwilling, to comprehend the masses. We may agree with Nandy that the incomprehension of sati expressed by the liberal media required examination and critique: after all, sati is only one among many practices exploitative of women. In a sense, contemporary liberal incomprehension parallels nineteenth-century colonial horror. Both cast sati simultaneously as an exceptional practice and one that is emblematic of society as a whole. The sense of its exceptionalism emerges in analyses of sati which treat it 
in isolation from women's subordination in general, while its emblematic status is dramatized in the way in which the incident has provoked anxiety about the nature and extent of India's social progress.

This, however, is not the direction in which Nandy develops his argument. Nandy's ire is directed mainly at what he perceives as the 'Western' modes of denouncing sati reproduced by 'modernists'. Nandy's stand on sati has drawn sharp criticism from feminists (Qadeer and Hasan, 1987; Patel and Kumar, 1988, Sangari, 1988; Philipose and Setalvad, 1988) whom he scorns as modernist, overlooking thereby important distinctions between feminist and liberal critiques of the practice (Nandy, 1988b). What is even more curious, however, is that Nandy's critique of the colonial mentality of these modernists itself reproduces three key moves of colonial discourse. He reaffirms the 'tradition'/modernity' dichotomy in analyzing the practice, and replicates the colonial oppositions, 'glorious past/degraded present' and 'authentic/inauthentic sati'. The latter two are brought together in his positive evaluation of the original, mythological sati, said to express women's sacred and magical powers, as against his negative description of contemporary widow burning which, he claims, is merely the product of a dehumanized market morality.

The fourth, and to my mind, genuinely anti-imperialist position (even though, unlike Nandy's it was not articulated as such) was that taken by feminists. Not surprisingly, concern for women's lives was very much at the centre of feminist discourse. Feminists insisted that Roop Kanwar's death should be understood in the context of the general subordination of women in Indian society, challenged attempts to frame the issue as one of tradition or religion and located the Deorala incident within post-independent political and economic developments in Rajasthan (Kishwar and Vanita, 1987; Bhasin and Menon, 1988; Vaid, 1988, among others). Feminists also pointed to the modernity of the incident and to the character of the pro-sati lobby, whose members were urban, educated men in their twenties and thirties. For example, Madhu Kishwar and Ruth Vanita argued that Deorala was not a rural backwater, but rather a prosperous town with electricity, tap water and a 70 per cent literacy rate (Kishwar and Vanita, 1987). Further, they pointed out that Roop Kanwar was a city-educated woman while her husband had a degree in science and her father-in-law, one of the abettors, was employed as a school teacher. In addition to the insufficiency of derisively analyzing sati as 'traditional', feminists argued that such a ploy would play into the hands of pro-sati 'traditionalists'. Religious arguments were similarly exposed as serving to legitimate the oppression of women. Again, Kishwar and Vanita described how the daily rituals around the spot where the burning had taken place resembled victory celebrations, not religious devotion. In arguing that cries of 'religion' could not absolve anyone of murder, Indira Jaising put it thus: 'just as the personal is political, the religious is secular where women are concerned' (Jaising, 1987).

Finally, feminists warned against the danger of demanding more 
stringent laws and greater state intervention, the recurring pleas of liberal opponents of sati. They highlighted the appalling lack of will demonstrated by the state in prosecuting Roop's in-laws, and the possibility that the state would merely abuse the greater powers that would accrue to it. These fears have largely been realized. Local police have used their powers to harass journalists and others investigating the case and, despite the law against abetting and glorifying sati, an estimated 8,000 people gathered at Deorala in September 1988 to 'celebrate' the one year anniversary of the burning of Roop Kanwar (Pachauri, 1988). And perhaps worst of all, one of the provisions of the legislative act on sati makes its victims liable to punishment: women who attempt sati are hereafter to be subject to fine or imprisonment!

The events that have followed Roop Kanwar's burning have radically changed the Indian context for my work. Widow burning is no longer, as it had been when I began, a 'historical' problem, but very much a charged and explosive contemporary issue. Although my own discussion here has focused most on feminist arguments, they are, alas, marginal to the current debate. The discursive space is principally being defined by conservatives and liberals. The former are more active in mobilizing a constituency and have had the support of political parties more wedded to securing votes than to fundamental rights of any kind. This context has made it imperative to contextualize and frame in particular ways some of the arguments I develop in my thesis.

How, for instance, might my critique of the civilizing mission be appropriated in the current situation? Part of my argument has been to show, in some detail, what is occluded in the following statement which represents a dominant story about colonialism and the question of woman: 'we came, we saw, we were horrified, we intervened'. Taking the instance of sati, whose abolition by the British in 1829 supposedly illuminates, par excellence, the legitimacy of this account, I have tried to suggest that the story is much more complicated. Among other things, I point out that legislative prohibition of sati was preceded by its legalization, a procedure that involved British officials in determining and enforcing a colonial version of the practice deemed traditional and authentic; that intervention in sati provided grounds for intervention in civil society; and that a fundamental ambivalence to sati structured colonial attitudes to the practice (Mani, 1987). I argue that missionary involvement in sati was similarly complex and ambivalent, with horror being reserved primarily for fundraising material produced for a British public. My point is that ultimately, for both officials and missionaries, women were not really at issue. Women rather provided ground for the development of other agendas.

I make a related argument about nineteenth-century indigenous discourses on sati. I argue that these developed within the constraints of a discourse on Indian society privileged by the British, that ambivalence to the practice is discernible even among those passionately opposed to sati, and that here too, concern for women seems secondary to concern for 'tradition' or for the general good of society. Women thus appear as 
obstacles to societal reform, and as individuals who must be trained to take up the duties of modern life with its own requirements of good wife and mother. My argument, then, has called into question the overly positive evaluation of the civilizing impulses of colonialism and the modernizing desires of proto-nationalism and nationalism: not because women did not gain from them, but because neither seemed to me to be selfless and benign in their espousal of women's rights, nor even centrally concerned with them.

How will such a critique of colonialist and nationalist arguments against sati resonate in India today? Is there any danger that my critique of the terms of these arguments will be read reductively as support for sati? Authorial intention, it is generally conceded, guarantees nothing. Considerable care will be necessary in framing my discussion in such a way that only a deliberate misreading can appropriate my arguments to reactionary ends. In addition, perhaps in my discussion of the nineteenth-century debate on sati I should also explicitly engage the contemporary moment so as to clarify how once again, with the signal exception of feminists and some progressives, arguments about women's rights have provided the basis for a further entrenchment of patriarchy in the name of 'tradition' (a point made by many Indian feminists) and for the arrogation of greater powers to the state in the name of 'modernity'.

I was lucky to be in India in the aftermath of Deorala. Lucky, because, in and of themselves, newspaper clippings and magazine articles could not have conveyed to me the political temperature there. Grasping the situation required the cumulative experience of countless conversations with friends, family members and neighbours, chance encounters on buses and trains, reports from feminists and civil libertarians who had travelled to Deorala, public meetings, and accounts of group discussions held in schools, colleges, political and community organizations. Much of this would obviously have been unavailable in print. My combined impressions strongly suggest that great care will have to be exercised in making arguments such as a critique of the Western civilizing mission.

The possible implications of other issues, such as exploration of the question of women's agency, appear to be even more treacherous. The problem of women's agency occupies a paradoxical position in feminist thinking in that, despite being a central concern, it remains poorly theorized. This is equally true of post-structuralist theory which, while being critical of the bourgeois conception of agency as the free will of an autonomous self, has yet to produce an adequate alternative formulation.

The widow's will has been a recurring theme in both the nineteenthand twentieth-century debates on sati. Here, discussion of agency is framed around the limited and analytically unhelpful binary terms, coercion and consent. Those defending sati have, then as now, made claims about the 'voluntary' nature of the act. Against this, opponents of sati have emphasized coercion, and questioned the meaning of consent. 
In the earlier debate, consent was sometimes conceived as impossible by definition: women were simply deemed incapable of it. At other times, the issue was formulated more broadly in terms of women's social position and of the meagre alternatives available to them. For instance, it was pointed out that one could hardly speak of consent when widowhood imposed its own regimes of misery. By and large, those against sati today have developed this latter argument, feminists far more consistently than liberals. In the colonial situation, this dualistic conception of agency led to legislation requiring women to be crossexamined at the pyre and being permitted to burn if their action was declared to be voluntary. A static conception of agency intersected with the assumption of religious hegemony to marginalize the ways in which women actively negotiated and struggled against the social and familial constraints upon them. Nowhere is this more evident than in colonial eyewitness accounts of sati, which consistently effaced signs of women's agency in struggle, resistance and coercion (Mani, 1989).

I have long felt anxious about how a broader consideration of women's agency is foreclosed by its reductive translation into an issue of whether or not the widow went willingly. Limiting discussion of women's agency in this way makes it difficult to engage simultaneously women's systematic subordination and the ways in which they negotiate oppressive, even determining, social conditions (Ong, 1987 and Gordon, 1989 develop such complex analyses of women's agency). I know that part of my own concern with these questions comes from a sense of the extent to which Third World peoples are consistently represented in Eurocentric discourses as lacking agency. I also know that it comes from a conviction that structures of domination are best understood if we can grasp how we remain agents even in the moments in which we are being intimately, viciously oppressed.

The discourse of woman as victim has been invaluable to feminism in pointing to the systematic character of gender domination. But if it is not employed with care, or in conjunction with a dynamic conception of agency, it leaves us with reductive representations of women as primarily beings who are passive and acted upon. In other words we are left with that common figure of Eurocentric feminist discourse: the Third World woman as 'always, already victim' (Mohanty, 1984). What is forsaken here is the notion of women's oppression as a multifaceted and contradictory social process. It is crucial to stress in this regard, however, that when Indian feminists speak of woman as victim it is in a complex material sense. It is also important to note than in emphasizing women's systematic subordination rather than debating questions of agency, Indian feminists are specifically attempting to counter rightwing discourse that falsely proposes women's total freedom. ${ }^{5}$

Questions of agency provoke issues at the heart of feminism. But in raising them in the current Indian context, one walks a tightrope. Firstly, given the dominant discourse on sati, to claim that women are agents even in their coercion is to court the possibility of misappropriation by the right wing. Secondly, current legislation on sati, by making 
women attempting sati liable to punishment, implicitly conceives of them as 'free agents'. The law states that any such punishment must take account of the circumstances in which the woman's decision was taken. But given that legal and political institutions routinely punish victims instead of perpetrators, why should we trust that this proviso will not work against women? In the short term, then, it seems safest to counter the notion of woman as free agent by emphasizing her victimization. However, unless we include in this a complex sense of agency, we run the risk of producing a discourse which sets women up to be saved. This would situate women within feminist analysis in ways that are similar to their positioning within colonialist or nationalist discourse.

The example of women's agency is a particularly good instance of the dilemmas confronted in simultaneously attempting to speak within different historical moments and to discrepant audiences. What might be a valuable pushing of the limits of current rethinking of agency in Anglo-American feminism, may, if not done with extreme care, be an unhelpful, if not disastrous move in the Indian context. If criticism is to be 'worldly' (Said, 1983: 1-30) or 'situated' (Haraway, 1988), or engaged, it must take account of the worlds in which it speaks. Perhaps to Bruce Robbins' suggestion that theory is a 'when' not a 'what,' (Robbins, 1987/8: 5) we should also add the notion of a 'where'.

\section{Notes}

Lata Mani received her Ph.D. from the University of California, Santa Cruz in 1989. She has been active in feminist struggles in India and in feminist and antiracist work in the US.

Kum-Kum Bhavnani, Vivek Dhareshwar, Ruth Frankenberg, Mary John and Kamala Visweswaran have left the imprint of their critical readings on the final version of this paper. I am also indebted to Indian feminists and progressives whose political insight and imaginative interventions in the contemporary debate on widow burning have been inspiring and instructive. An earlier version of this paper appeared in Inscriptions, no. 5, University of California, Santa Cruz, 1989.

1 The relative rapidity with which the concept of 'culture studies' has found institutional support in the US academy compared to ethnic or women's studies should give us pause. bell hooks (Gloria Watkins) and Gayatri C. Spivak have recently mapped out what is at stake intellectually and politically in the kinds of theoretical and curricular agendas being privileged and excluded in the institutionalization of 'Third World' or 'culture studies'. bell hooks, 'Critical integration: talking race, resisting racism', Conference on Feminisms and Cultural Imperialism: The Politics of Difference, Cornell University, 1989 April 22-3; Gayatri C. Spivak, 'Post-coloniality and the field of value', Conference on Feminisms and Cultural Imperialism: The Politics of Difference, Cornell University, 1989, April 22-3. 
2 As a whole, however, as Norma Alarcon (forthcoming), Aida Hurtado (1989) and Chela Sandoval (forthcoming) have recently argued, the critique of US white feminism has been taken up very unevenly and has failed fundamentally to transform dominant feminist thinking.

3 Edward Said (1986) raises the problem of discrepant experiences and constituencies but develops instead a case for foregrounding the shared intellectual and political terrain produced by colonialism. See also, Said, 1983: 226-47).

4 There may be many reasons for a critique of Said's Orientalism, some more persuasive than others (Mani and Frankenberg, 1985). There is firstly the theoretical resistance of those working within an objectivist paradigm to his social constructionist approach. Then there is the question of the scope of his argument. Many Indian readers, for example, felt that the book's value for them was seriously limited by its primary focus on the West and its lack of analysis of internal class and power relations in colonized territories. My point here, then, is not that there are no grounds to criticize Orientalism: rather that, in India, the political and ideological impetus of Said's project has generally not been apprehended as compelling, a response tied to both geographical location and historical experience.

5 Rajeswari Sunder Rajan is approaching the problem of the widow's subjectivity in sati from a different perspective. She argues that the 'methodological impasse' generated by the 'coercion-consent' framework can be avoided if the question of the widow's subjectivity is engaged via an exploration of 'both the phenomenology of pain and a politics that recognizes pain as constitutive of the subject' (forthcoming).

\section{References}

AlARCON, N. (forthcoming) 'The theoretical subject(s) of This Bridge Called My Back and Anglo-American feminism', in CALDERON and SALDIVAR.

AMOS, V., LeWIS, G., MAMA, A. and PARMAR, P. (1984) editors, 'Many voices, one chant: Black-feminist perspectives', Feminist Review, no. 17.

ANZALdUA, G. (1987) Borderlands/La Frontera: The New Mestisa, San Francisco: Spinsters/Aunt Lute.

APPADURAI, A. (1988) 'Putting hierarchy in its place', Cultural Anthropology, vol. 3 , no. 1 .

BHASIN, K. and MENON, R. (1988) 'The problem', Seminar, no. 342, Special Issue on sati.

BHAVNANI, K-K. and COULSON, M. (1986) 'Transforming socialist-feminism: the challenge of racism', Feminist Review, no. 23.

BUlkIN, E., PRATT, M. B. and SMITh,'B. (1984) Yours in Struggle: Feminist Perspectives on Racism and Anti-Semitism, New York: Long Haul Press.

CALDERON, Hector and SALDIVAR, Jose D. (forthcoming) editors, Chicano Criticism in a Social Context, Durham: Duke University Press.

CENTRE FOR CONTEMPORARY CULTURAL STUDIES (1982) The Empire Strikes Back: Race and Racism in 70s Britain, London: Hutchinson.

DE LAURETIS, T. (1986) editor, Feminist Studies/Critical Studies, Bloomington: Indiana.

DE LAURETIS, T. (1990) 'Eccentric subjects: feminist theory and historical consciousness', Feminist Studies. 
ENGINEER, A. A. (1987) The Shahbano Controversy, Bombay: Orient Longman.

GORDON, L. (1989) Heroes of their Own Lives, The Politics and History of Family Violence, New York: Penguin.

GREWAL, S., KAY, J., LANDOR, L., LEWIS, G. and PARMAR, P. (1988) editors, Charting the Journey: Writings By Black and Third World Women, London: Sheba.

HARAWAY, D. (1988) 'Situated knowledges: the science question and the privilege of partial perspective', Feminist Studies, vol. 14, no. 3 .

Hooks, B. (1981) Ain't I A Woman: Black Women and Feminism, Boston: South End Press.

HURTADO, A. (1989) 'Relating to privilege: seduction and rejection in the subordination of white women and women of color', Signs, vol. 14, no. 4 .

INDEN, R. (1986) 'Orientalist constructions of India', Modern Asian Studies, vol. 20 , no. 3 .

JAISING, I. (1987) 'Women, religion and the law', The Lawyers Collective, vol. 2, no. 11.

KAPLAN, C. (1987) 'Deterritorializations: the rewriting of home and exile in Western feminist discourse', Cultural Critique, no. 6.

KISHWAR, M. (1986) 'Pro-woman or anti-Muslim? The Shahbano controversy', Manushi, no. 32.

KISHWAR, M. and VANITA, R. (1987) 'The burning of Roop Kanwar', Manushi, no. $42-3$.

LAZREG, M. (1988) 'Feminism and difference: the perils of writing as a woman on women in Algeria', Feminist Studies, vol. 14, no. 1.

MANI, L. and FRANKENBERG, R. (1985) 'The challenge of Orientalism', Economy and Society, vol. 14, no. 2.

MANI, L. (1987) 'Contentious traditions: the debate on sati in colonial India', Cultural Critique, no. 7; also published in SANGARI and VAID 1989.

MANI, L. (1989) 'Contentious traditions: the debate on sati in colonial India, 1780-1833', Ph.D. diss., University of California, Santa Cruz.

MINH-HA, TRIHN, T (1986/7) editor, 'She the inappropriate/d Other', Discourse, no. 8.

MOHANTY, C. T. (1984) 'Under Western eyes: feminist scholarship and colonial discourses', Boundary 2, Spring/Fall, vol. 12, no. 3/vol. 13, no. 1. (revised, 1988, Feminist Review, no. 30).

- (1987) 'Feminist encounters, locating the politics of experience', Copyright, vol. 1 , no. 1 .

MOHANTY, S. P. (1989) 'Us and them: on the philosophical bases of political criticism', Yale Journal of Criticism, vol. 2, no. 2.

MORAGA, C. and ANZALDUA, G. (1981) editors, This Bridge Called My Back: Writings By Radical Women of Color, Watertown Mass: Persephone.

NANDY, A. (1987) 'The sociology of sati', Indian Express, October 5.

- (1988a) 'The human factor', The Illustrated Weekly of India, January 17, 1988 .

- (1988b) 'Sati in Kaliyuga', Economic and Political Weekly, September 17.

ONG, A. (1987) Spirits of Resistance and Capitalist Resistance: Factory Women in Malaysia, Albany: SUNY Press.

PACHAURI, P. (1988) 'Turning a blind eye: glorification of sati continues despite the law', India Today, October 15.

PARMAR, P. (1982) 'Gender, race and class: Asian women in resistance', in CENTRE FOR CONTEMPORARY CULTURAL STUDIES (1982).

PATEL, S. and KUMAR, K. (1988) 'Defenders of sati', Economic and Political Weekly, January 23. 
PATHAK, Z. and SUNDER RAJAN, R. (1989) ' "Shahbano"', Signs, vol. 14, no. 3.

PHILIPOSE, P. and SETALVAD, T. (1988) 'Demystifying sati', The Illustrated Weekly of India, March 13.

PUNWANI, J. (1985) 'The strange case of Shahbano', The Sunday Observer, November 24.

QADEER, I. and HASAN, z. (1987) 'Deadly politics of the state and its apologists', Economic and Political Weekly, November 14.

RICH, A. (1986) 'Notes toward a politics of location (1984)', in Blood Bread and Poetry, New York: Norton.

ROBBINS, B. (1987/8) 'The politics of theory', Social Text, no. 18.

SAID, E. (1979) Orientalism, New York: Vintage.

- (1983) The World The Text and the Critic, Cambridge: Harvard University Press.

(1986) 'Intellectuals in the post-colonial world', Salmagundi, no. 70-1.

SANDOVAL, C. (forthcoming) 'US Third World feminism: the theory and method of oppositional consciousness', in 'Oppositional consciousness in the post-modern world', Doctoral dissertation in progress, University of California, Santa Cruz.

SANGARI, K. K. (1988) 'Perpetuating the myth', Seminar, no. 342, Special Issue on Sati.

SANGARI, K. K. and VAID, S. (1989) editors, Recasting Women: Essays on Colonial History, New Delhi: Kali.

SEGREST, M. (1985) My Mama's Dead Squirrel: Lesbian Essays on Southern Culture, Ithaca, NY: Firebrand Books.

SMITH, B. (1983) editor, Home Girls: A Black Feminist Anthology, New York: Kitchen Table/Women of Color Press.

SPIVAK, G. C. (1981) 'French feminism in an international frame', Yale French Studies, no. 62.

SUNDER RAJAN, R. (forthcoming) 'The subject of sati: Pain and death in the contemporary discourse on Sati', Yale Journal of Criticism.

VAID, S. (1988) 'Politics of Widow Immolation', Seminar, no. 342, Special Issue on Sati. 